an exhibition of living bacteria such as more or less affect the well-being of the human race.

It is to be hoped that this report will be widely read in this country by all who are concerned with the management of museums, for it is full of most valuable information, and it is becoming increasingly clear that the museum is becoming more and more a factor in the well-being of the community. W. P. P.

\section{FORTHCOMING BOOKS OF SCIENCE.}

ANTHROPOLOGY AND ARCHAOLOGY.

A. Brown and Son, Ltd.-Early Staffordshire Pottery, being an illustrated description, by C. Earle, of the Earle Collection, deposited in the Municipal Museum, Hull, with a preface by F. Falkner, and an introductory chapter on The Evolution of the Potter's Art, by T. Sheppard. Cambridge University Press.The Northern Bantu: An Account of some Central African Tribes of the Uganda Protectorate, Rev. J. Roscoe (Cambridge Archæological and Ethnological Series). Duckworth and Co.-Where Animals Talk: Folk Tales of West Africa, Rev. R. H. Nassau. Seeley, Service and Co., Ltd.-Prehistoric Man and His Story, Prof. G. F. Scott Elliot, illustrated. Macmillan and Co., Ltd.--An Untamed Territory: The Northern Territory of Australia, Elsie R. Masson, illustrated; The S.P.C.K.-The Language Families of Africa; A. Werner; The Red Indians of Canada, Rev. J. Hines, illustrated. Williams and Norgate.-The Antiquity of Man, Prof. A. Keith, illustrated.

Biology.

F. Alcan (Paris).-L'Evolution des Plantes, N. Bernard. John Bale, Ltd.-Les Plantes Tropicales, P. de Sornay, translated; Rubber Industry of the Amazon, J. F. Woodroffe; Guide to Cocoanut Planting, R. W. Munro and L. C. Brown; Braun's Animal Parasites : brought up to date, mostly rewritten, with numerous additions and fresh illustrations, by Prof. Stephens and Dr. H. B. Fantham, edited by F. V. Theobald. Cambridge University Press.-Botany: A Text-Book for Senior Students, D. Thoday; Mimicry in Butterflies, Prof. R. C. Punnett. Cassell and Co., Ltd.-The Greenhouse : Its Flowers and Management, H. H. Thomas; Bulb Growing for Amateurs, H. H. Thomas. Dulau and Co., Ltd.-The Flowering Plants of Africa, F. Thonner, illustrated. Duckworth and Co.-Birds and Man, W. H. Hudson, new edition. H. Holt and Co. (New York).-Mechanism of Mendelian Heredity, T. H. Morgan and others. Longmans and Co.-British Birds, written and illustrated by A. Thorburn, vols. ii., iii., and iv. Methuen and Co., Ltd.-How to Know the Ferns, S. L. Bastin, illustrated; British Insects and How to Know Them, H. Bastin, illustrated. L. Reeve and Co., Ltd.Transactions of the London Natural History Society for the Year roI4. Whittaker and Co.-Recent Researches in Plant Physiology, Dr. W. R. G. Atkins.

\section{Chemistry.}

G. Bell and Sons, Ltd.--Quantitative Laws in Biological Chemistry, Dr. Svante Arrhenius. C. Griffin and Co., Ltd.--Text-Book of Inorganic Chemistry, edited by Dr. J. Newton Friend; The Allzali Metals and their Congeners (Group I. of the Periodic Table). Dr. A. J. Walker; The Alkaline Earth Metals and their Associates (Group II. of the Periodic Table), Dr. H. V. A. Briscoe and E. Sinkinson; Aluminium and its Congeners, including the Rare Earth Metals (Group III. of the Periodic Table), H. F. V. Little: Carbon and its Allies (Group IV. of the Periodic Table), Dr. R. M. Caven; Nitrogen and its Congeners (Group V. No. 2395 , vol. 96] of the Periodic Table), Dr. J. C. Withers and H. F. V. Little; Sulphur and its Congeners (Group VI. of the Periodic Table), Dr. Douglas F. Twiss and A. V. Eldridge; The Halogens and their Allies (Group VII. of the Periodic Table), Dr. G. Martin and E. A. Dancaster; Iron and the Transitional Elements (Group VIII. of the Periodic Table), Dr. J. N. Friend and Dr. W. E. S. Turner; The Manufacture of Ink: The Production and Properties of Printing, Writing, and Copying Inks, C. A. Mitchell and T. C. Hepworth, new edition, illustrated. Gurney and Jackson.-The Manufacture of Sulphuric Acid and Alkali, vol. iv., containing Electrolytical Methods, Prof. G. Lunge; Coal Tar and Ammonia, Prof. Lunge and Dr. J. Kraemer, new edition. Longmans and Co.-Chemistry, First Stage, F. P. Armitage. Methuen and Co., Ltd.-A Senior Experimental Chemistry, Drs. A. E. Dunstan and F. B. Thole. John Wiley and Sons, Inc. (New York).-Quantitative Chemical Analysis, Prof. F. A. Gooch; The Microscopy of Vegetable Foods, Dr. A. L. Winton, new edition. Williams and Norgate.-The British Coal-Tar Industry : its Origin, Development, and Decline, edited by Prof. W. M. Gardner, illustrated.

\section{ENGINEERING.}

Chapman and Hall, Ltd.-The Strength of Materials: A Text-Book for Engineers and Architects, E. S. Andrews, illustrated. Constable and Co., Ltd.Overhead Transmission Lines and Distributing Circuits, F. Kapper, translated by P. R. Friedlaender, illustrated; Oil Fuel Equipment for Locomotives, A. H. Gibbings, illustrated; Practical Design of Steel Framed Sheds, A. S. Spencer, illustrated; Continuous Current Enyineering, Dr. A. Hay, new edition, illustrated. C. Griffin and Co., Ltd.-Land and Marine Diese Engines, Prof. Supino, translated by Engr.-Commdr. A. G. Bremner and J. Richardson, illustrated; Centrifugal Pumps, E. W. Sargeant, illustrated. Scott, Greenwood and Son.-Portland Cement: Its Properties and Manufacture, P. C. H. West; Design of Machine Tools, G. W. Burley; Bridge Foundations, W. Burnside; Calculations for a Steel Frame Building, W. C. Cocking; Gear Cutting, G. T. White; Moving Loads by Influence Lines and Other Methods, E. H. Sprague; The Stability of Arches, E. H. Sprague; Drawing Office Practice, W. Clegg; Estimating Steelwork for Buildings, S. Bylander and P. F. Gleed; The Theory of the Centrifugal and Turbo Pump, J. W. Cameron; Strength of ships, J. B. Thomas; The Thrust of Earthwork and the Design of Retaining Walls, E. H. Sprague. The University Tutorial Press, Ltd.-A First Course in Engineering Science, P. J. Haler and A. H. Stuart. Whittaker and Co.-High Speed Internal Combustion Engines, W. E. Dommett; Gas and Petroleum Engines, H. Garrard. John Wiley and Sons, Inc. (New York).Elements of Highway Engineering, Prof. A. H Blanchard; Elements of Railroad Track and Construction, Prof. W. L. Wilson, new edition; Field Engineering, W. H. Searles and Prof. H. C. Ives, new edition, 2 vols.; Graphics and Structural Design, Prof. H. D. Hess, new edition; Theory and Practice of Modern Framed Structures, part 3, Design, J. B. Johnson, C. W. Bryan, and F. E. Turneaure, new edition; Elements of Refrigeration, Prof. A. M. Greene, jun.; Engineering Thermodynamics, Prof. J. A. Moyer and J. P. Calderwood; Mechanical Equipment of Buildings, Profs. L. A. Harding and A. C. Willard; Mechanical Engineers' Pocket Book, Dr. W. Kent, new edition; Steam Boiler Economv, Dr. W. Kent, new edition; Alternating Current Electricity and its Applications to Industry, W. H. Timbie and Prof. H. H. Higbie, second course. 


\section{Geography and Travel.}

F. Alcan (Paris).-Géographie des Cours Complémentaires et du Brevet élémentaire, Prof. J. Fèvre and Prof. H. Hauser, illustrated. A. and C. Black, Ltd. Some Frontiers of To-morrow: An Aspiration for Europe, Prof. L. W. Lyde; Commercial Geography, A. L. Curr, illustrated; Beginners' Regional Geography: Asia; the British Isles; the Americas; J. B. Reynolds, illustrated. Constable and Co., Ltd.Geographical Aspects of Balkan Problems, Dr. M. I. Newbigin, illustrated. Macmillan and Co., Ltd.The Ibex of Shä-Ping, and other Himalayan Studies, Lieut. L. B. Rundall, illustrated. Methuen and Co. Ltd.-On Alpine Heights and British Crags, G. D. Abraham, illustrated. John Murray.-Hunting Pygmies, Dr. W. E. Geil, illustrated. Seeley, Service and Co., Ltd.-A Naturalist in Madagascar: the record of over fifty years' intimate intercourse with the natives of Madagascar, and the result of observations of the animal and vegetable life of the island, Dr. J. Sibree, illustrated.

\section{Geology.}

H. Holt and Co. (New York).--Metamorphic Geology, C. K. Leith and W. J. Mead. T. Murby and Co.-Rutley's Elements of Mineralogy, H. H. Read, new edition, revised, illustrated. John Wiley and Sons, Inc. (New York).-Microscopical Determination of the Opaque Minerals: An Aid to the Study of Ores, Dr. J. Murdock; Principles of Oil and Gas Production, Prof. R. H. Johnson and L. G. Huntley; The System of Mineralogy of J. D. Dana, Prof. W. E. Ford, third appendix to the sixth edition; Text Book on Geology, Prof. L. V. Pirsson and C. Schuchert.

\section{Mathematrcal and Physical Sciences.}

F. Alcan (Paris).-Le Radium, Prof. F. Soddy, traduit de l'anglais, A. Lepage; Cours d'Algèbre et d'Analyse, Prof. C. Michel; Cours d'Algèbre, Prof. Girod, 2 vols. Cambridge University Press.-Sir George Darwin's Collected Papers, vol. v., with Memoirs; An Introduction to Applied Mechanics, E S. Andrews, illustrated (Cambridge Technical Series); Modern Analysis, Prof. E. T. Whittaker, new edition, in which the author has secured the collaboration of G. N. Watson; Spectroscopic Papers: Collected reprints of investigations which have already appeared in the Transactions of the Royal Society and elsewhere, Dr. Liveing and Sir James Dewar; Euclid's Book on the Division of Figures, Prof. R. C. Archibald. $W$. and $R$. Chambers, Ltd.-Five-Figure Mathematical Tables, E. Chappell. Chapman and Hall, Ltd.-Arithmetic for Engineers, C. B. Clapham; Mathematics for Engineers, W. N. Rose. Constable and Co., Ltd.-Atoms, J. Perrin, translated by D. L1. Hammick, illustrated. C. Griffin and Sons, Ltd.Sound: Being vol. ii. of A Text-Book of Physics, Dr. J. H. Poynting and Sir J. J. Thomson, new edition. Longmans and Co.-An Introduction to the Mechanics of Fluids, Prof. E. H. Barton; Stars of the Southern Skies, M. A. Orr (Mrs. John Evershed). The Open Court Combany.-Dr. Morgan's Budget of Paradoxes, edited by Prof. D. E. Smith, 2 vols.; The Principles of Mechanics with Newton and his Contemporaries, P. E. B. Jourdain. Seeley, Service and Co., Ltd.-The Stars and their Mysteries, C. R. Gib son, illustrated. The S.P.C.K.-A Voyage Through Space: Lectures, much expanded, delivered at the Royal . Institution, Christmas, I9I3, Prof. H. H. Turner, illustrated. The University Tutorial Press, Ltd.--Rural Arithmetic, A. G. Ruston; Higher TextBook of Magnetism and Electricity, R. W. Hutchin- son. Whittaker and Co.-Telegraphy, T. E. Herbert; Practical Exercises in Magnetism and Electricity, Dr. J. R. Ashworth. John Wiley and Sons, Inc. (New York).-Analytic Geometry, Prof. H. B. Philips; Diophantine Analysis, Prof. R. D. Carmichael; Mathematical Tables for Classroom Use, M. Merriman; Theory and Application of Finite Groups, Profs. H. F. Blickfeldt, G. A. Miller, and L. E. Dickson.

\section{Medical Science.}

G. Bell and Sons, Ltd.-Radium, X-Rays and the Living Cell, with Physical Introduction, H. A. Colwell and Dr. S. Russ, illustrated; Tuberculosis: A General Account of the Disease, its Treatment, and Prevention, Dr. A. J. Jex-Blake. A. and C. Black, Ltd.-The Structure of the Fowl, Dr. O. C. Bradley, illustrated; The Pocket Prescriber, Dr. J. Burnet, illustrated. Cassell and Co., Ltd.Personal Hygiene for Boys, Dr. L. Anderson; Serums, Vaccines, and Toxins in Treatment and Diagnosis, Dr. W. C. Bosanquet and Dr. J. W. H. Eyre, new edition, illustrated; Diseases of the Nose and Throat, comprising Affections of the Trachea and CEsophagus, Sir St. Clair Thomson, new edition, illustrated; Disease of the Nervous System, Dr. H. C. Thomson, new edition, illustrated. $J$ and $A$. Churchill.-A Text-book of Surgery, R. Warren, illustrated; The Primary Lung Focus in Tuberculosis in Children, Dr. A. Ghon, translated by Dr. D. Barty King, illustrated; Catalysis and its Industrial Applications, E. Jobling, illustrated; The Operations of Surgery, W. H. A. Jacobson, new edition, revised by R. P. Rowlands and P. Turner. H. K. Lewis and Co., Ltd.-Mentally Deficient Children: their Treatment and Training, Drs. G. E. Shuttleworth and W. A. Potts, new edition; Heart Sounds and Murmurs : their Causation and Differentiation, Dr. E. M. Brockbank, new edition. Longmans and Co.-Principles of General Physiology, Prof. W. M. Bayliss, illustrated. Methuen and Co., Ltd.-Mind Cures, G. Rhodes; The Care of the Teeth, A. T. Pitts; The Eyes of Our Children, N. B. Harman; The Care of the Body, Dr. F. Cavanagh; The Prevention of the Common Cold, Dr. O. K. Williamson; The Hygiene of the Skin, Dr. G. Pernet; The Health of a Woman, Dr. H. J. F. Simson; How to Live Long, W. Carr. John Murray.-Rural Sanitation in the Tropics: From Notes and Observations on the Malay Peninsula, in Panama and other Lands, Dr. M. Watson, illustrated; A Handbook of Physiology, Prof. W. D. Halliburton, new edition, illustrated.

\section{Metallurgy.}

C. Griffin and Co., Ltd.-Researches on Special Steels, Sir R. Hadfield, illustrated; The Metallurgy of Steel, F. W. Harbord and J. W. Hall, new edition, 2 vols., illustrated; The Physico-Chemical Properties of Steel, Prof. C. A. Edwards; The Metallurgy of Iron, Prof. T. Turner, new edition, illustrated; The Value of Science in Smithy and Forge, Dr. W. H. Cathcart, edited by Dr. I. E. Stead; The Gold Deposits of the Rand, C. B. Horwood, illustrated; Metallurgical Analysis and Assaying: A Three-Years' Course for Students of Schools of Mines, W. A. Macleod and C. Walker.

\section{TECHNOLOGY.}

Cassell and Co., Ltd.-Model Engineering, $\mathrm{H}$. Greenly; Furniture Making, R. S. Bowers and other designer-craftsmen; The Cinematograph Book, edited by B. E. Jones; Toy Making. Constable and Co., Ltd.-Mechanical Technology, Prof. G. F. Charnock, illustrated. "The Electrician" Printing and Publishing Co., Ltd.-The Manufacture of Electric Arc

No. 2395, VOL. 96] 
Carbons; Theory of the Submarine Telegraph Cable, Dr. H. W. Malcolm; Wireless Telegraphy and Telephony, Dr. W. H. Eccles; Electric Switch and Controlling Gear, Dr. C. C. Garrard; The Electrical Laboratory and Testing Room, vols. i. and ii., Dr. J. A. Fleming; Primary Batteries: their Construction and Use, W. R. Cooper, new edition; The Localisation of Faults in Electric Light Mains, F. C. Raphael, new edition. C. Griffin and Co., Ltd.-Refractory Materials : their Manufacture and Uses, A. B. Searle, illustrated; Vinegar: its Manufacture and Examination, C. A. Mitchell, illustrated; The Construction of Dams (Earthen and Masonry), Prof. E. R. Matthews, illustrated; Briquetting: Coal, Shale, Ores, Metal Swarf, etc., G. Franke, translated and edited by F. Lantsberry, 2 vols.; Autogenous Welding, R. Granjon and P. Rosemberg, translated by D. Richardson, new edition. H. Holt and Co. (New York).-Commerce and Industry, J. R. Smith. John Wiley and Sons, Inc. (New York).-Decorative Design: A Text-Book of Practical Method, J. C. Chase; Mechanical Drafting, C. B. Howe.

George Allen and Unwin, Ltd.-The Great Problems, Prof. B. Varisco, translated by Prof. R. C. Lodge; Know Thyself, Prof. B. Varisco, translated by Dr. G. Salvadori. Duckworth and Co.-Foundations of Normal and Abnormal Psychology, Dr. B. Sidis; Child Training, C. V. Hillyer, illustrated. Wells Gardner, Dalton and Co., Ltd.-Story Lives of Men of Science, F. J. Rowbotham. C. Griffin and Co., Ltd.-Practical Surveying and Field-Work, including the Mechanical Forms of Office Calculations, with Examples, completely worked out, V. G. Salmon; Practical Hydraulics for Mining Students, Prof. J. Park, illustrated; Theodolite Surveying, Prof. J. Park, new edition, illustrated; An Enquiry into the Statistics of Deaths from Violence and Unnatural Causes in the United Kingdom: with Special Reference to Deaths from Starvation, Overlying of Infants, Burning, Administration of Anæsthetics, and Poisoning, Dr. W. A. Brend. Longmans and Co.-What Should I Believe? An Inquiry into the Nature, Grounds and Value of Science, Society, Morals, and Religion, Prof. G. T. Ladd. Macmillan and Co., Ltd.-Second Thoughts of an Economist, the late Prof. W. Smart; An Introduction to Ethics for Training Colleges, G. A. Johnston; Mind in Evolution, L. T. Hobhouse, new edition. Methuen and Co., Ltd.-Grovernment by Natural Selection, H. Taylor. G. P. Putnam's Sons.-Social Progress and the Darwinian Theory, Dr. G. W. Nasmyth; Darwin and the Humanities, Dr. J. M. Baldwin. John Wiley and Sons, Inc. (New York).-A Meteorological Treatise on the Circulation and Radiation in the Atmospheres of the Earth and of the Sun, Prof. F. H. Bigelow.

\section{THE BRITISH ASSOCIATION. SECTION C. \\ GEOLOGY.}

Opening Address ${ }^{1}$ by Prof. Grenville A. J. Cole, F.G.S., M.R.I.A., President of the Section.

THE geologist has long been accustomed to regard the crust beneath his feet as subject to changes which are immeasurably slow in comparison with the duration of his personal life. James Hutton has sometimes been charged with catastrophic tendencies, in requiring a complete wearing away of the continents, followed by a somewhat

$$
1 \text { Abridged by the author. }
$$

sudden restoration of the land-surface. But he was careful to urge ${ }^{2}$ that "the powers of nature are not to be employed in order to destroy the very object of those powers; we are not to make nature act in violation to that order which we actually observe." He remarks ${ }^{3}$ that "this world is thus destroyed in one part, but it is renewed in another; and the operations by which this world is thus constantly renewed are as evident to the scientific eye as are those in which it is necessarily destroyed." Yet the operations that are to "give birth to future continents," as well as those that wear down a continent to the level of the sea, are not the result of "any violent exertion of power, such as is required in order to produce a great event in little time; in nature, we find no deficiency in respect of time, nor any limitation with regard to power." Far from believing in the complete loss of the former land-surface before upheaval raised the new, Hutton points out that "the just view is this, that when the former land of the globe had been complete, so as to begin to waste and be impaired by the encroachment of the sea, the present land began to appear above the surface of the ocean. In this manner we suppose a due proportion to be always preserved of land and water upon the surface of the globe, for the purpose of a habitable world, such as this which we possess."

Changes in the Relative Proportions of Sea and Land.

Few geologists, however, will now urge with Hutton that a "due proportion" has always been preserved between land and water on the surface of the globe, if by those words is meant a proportion such as we now enjoy. If we go back to early times, we must consider, with R. A. Daly, the possible grouping of the land against which the Huronian or late pre-Cambrian sediments were formed. Daly has imagined, as one of the causes contributing to a "limeless ocean," a primitive distribution of land and water very different from that which determines our continental land to-day. His pre-Huronian landsurface is pictured as merely a number of large islands, on which no long and conspicuous rivers could arise.

It may be said that this primitive condition of the distribution of land and water is very unlikely to return. But we have evidence that Hutton's "due proportion" has been interfered with from time to time. The very general spread of the sea over the landmargins in Cenomanian times is attributable to a shallowing of the ocean-floors, and it is difficult to say whether this process has been rhythmic or exceptional in the history of the globe. The Carboniferous period opened with marine conditions over a large part of the northern hemisphere, indicating, not only a continuation of the Devonian seas, but an overflowing of much of the Caledonian land. The same period closes with an extension of the continental edges, and the formation of swampy flats, in which the vegetation of the epoch has been abundantiy preserved. Similarly, the sea which deposited the Cretaceous strata, after encroaching alike on South Africa and Scandinavia, withdrew to a considerable extent in Eocene times.

\section{The Foundations of the Earth's Crust.}

Hutton remains at present unassailable in one of his most remarkable propositions. For him, the oldest rocks that we know are sedimentary, and these sediments differed in no respect from those of modern days. This conclusion has perhaps not received the full attention it deserves. It now appears

2 "Theory of the Earth" (r795), vol. ii., p. 547.

3 Ibid., p. 562

4 "The Limeless Ocean of Pre-Cambrian Time," Aner. Journ. Sci., vol. xxiii. (1907), p. Ir 3 ; and more fully in "First Calcareous Fossils," Bull. Geol. Soc. America, vol. xx. (1909), p. $\mathrm{I}_{57}$. 